INSIGHTS INTO REGIONAL DEVELOPMENT

ISSN 2669-0195 (online) http://jssidoi.org/IRD/

2019 Volume 1 Number 4 (December)

http://doi.org/10.9770/IRD.2019.1.4(5)

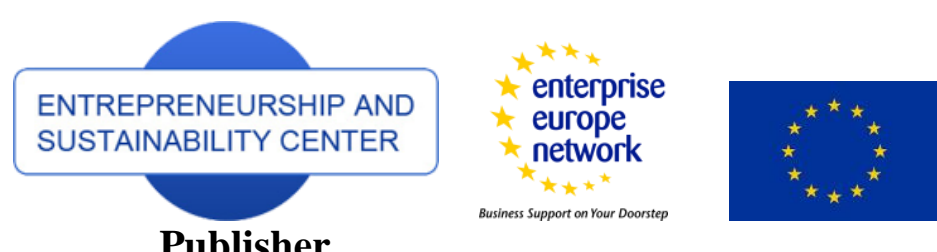

http://jssidoi.org/esc/home

\title{
REGIONAL AND PRODUCT PROFILE OF POST-INDUSTRIAL SERVICES IN THE ECONOMY OF KAZAKHSTAN*
}

\author{
Yerkenazym Orynbassarova ${ }^{1}$, Ergaly Abzalbek ${ }^{2}$, Tatyana Pritvorova ${ }^{3}$, \\ Yelena Petrenko ${ }^{4 *}$ \\ ${ }^{1,4}$ Karaganda Economic University of Kazpotrebsoyuz, Akademicheskaya 9, Karaganda, Kazakhstan \\ ${ }^{2,3}$ Ye.A. Buketov Karaganda State University, Universitetskaya 28, Karaganda, Kazakhstan \\ E-mails: ${ }^{1}$ rke.08@mailru; ${ }^{2}$ abzalbeky@bk.ru; ${ }^{3}$ pritvorova_@mail.ru; ${ }^{4}$ petrenko_yelena@bk.ru
}

Received 16 July 2019; accepted 15 September 2019; published 15 December 2019

\begin{abstract}
The article examines the post-industrial services sector in the economy of Kazakhstan, the state and dynamics of which is a characteristic feature of the modern techno-technological structure in the post-industrial countries of the world. The sector includes information and communication, business and professional services. The authors study the regional profile of the post-industrial services in Kazakhstan and identify the level of centralization of these types of activities in the regions of Kazakhstan, as well as the nature of its dynamics. Using the method of rating assessment and the method of absolute differences to group regions by the volume of the postindustrial services in the medium term, the authors give a qualitative description of the selected groups. Concerning the product profile of the types of activities as a part of post-industrial services, the authors conduct a dynamic analysis of all types of services within three aggregated positions: computer programming services; information services; services in the field of architecture, engineering surveys, technical tests and analysis. The article assesses the characteristics of the dynamics and structure of supply in the markets of these services, the concentration of services in the regions of Kazakhstan. The types of services that are characterized by the absolute and relative growth in all the regions of the country are identified, which makes it possible to draw conclusions about the vector of development of the economy of Kazakhstan as a whole. The main positive trend is the emergence in the first place of the specific gravity and growth rate of engineering services, which generally corresponds to the trend of transition towards the post-industrial economy with its emphasis on services for all the sectors. Since engineering services are complementary to the real sector of the economy, we can positively assess this trend in the development of Kazakhstan.
\end{abstract}

Keywords: postindustrial services; business and professional services; information services; regional profile; rating

Reference to this paper should be made as follows: Orynbassarova, Y., Abzalbek, E., Pritvorova, T., Petrenko, Y. 2019. Regional and product profile of post-industrial services in the economy of Kazakhstan. Insights into Regional Development, 1(4), 343-355. https://doi.org/10.9770/ird.2019.1.4(5)

\footnotetext{
* This research was supported by the project, which has received funding from the Ministry of Education and Science under the grant of "Best teacher of the university - 2018” http://edu.gov.kz/m/news/detail.php?ELEMENT_ID=11522
} 


\section{Introduction}

The growth stages theory (Rostow 1973), the theory of the post-industrial society (Toffler 2010), (Bell 1986) lay the system of initial representations for the modern concepts of the knowledge economy, the change of technotechnological paradigms, innovative economics, and the post-industrial society.

Offering a research methodology for the modern post-industrial economy, they identified many areas in economic science, based on the idea of the driving forces of the post-industrial stage of production and its empirical forms. National innovation systems (Lundvall 1992), clusters (Porter 2011), interactive scientific and educational structures (Kravets 2016), network communities (Verchenov et.al. 2017), business ecosystems and platform technologies (Muegge 2013, Weill 2018), etc. have become such forms.

The main feature of a complex system of post-industrial economy is the support in the production of goods on services that have high added value, i.e. are high tech. Such a quality of services appears as a result of the use of information and electronic technologies in their production, which provide for a transition to a new level of labor productivity, marketing, logistics, etc. (Lidtka 2015, Tapskott 2009)

According to this methodology, the country's transition to the post-industrial stage of development is diagnosed on the basis of positive structural changes in the share of information and communication, business and professional services, which are included in the production process at its intermediate stage and have a decisive effect on the final product or the final result in the form of a service.

For Kazakhstan, which has set the goal of becoming one of the thirty most competitive countries in the world, one of the urgent tasks of development is structural restructuring of the economy and implementation of the development programs aimed at establishing a modern post-industrial structure of the economy (Nazarbayev 2018, Information Kazakhstan - 2020).

\section{Research background}

In the developed countries, a significant array of studies is devoted to services with intensive use of knowledge, the most interesting of which, in our opinion, are publications (Sarkar et al 2016, Tachiciu 2016, Zenka et al 2017, Zhou et al 2017). In the post-Soviet space, the research of (Inozemtsev 2007, Varnavskiy 2016, Demidova 2010, Kondratyev 2011, Kraft 2017) and others is devoted to the development of services in the post-industrial economy.

At the same time, in Kazakhstan science, a systematic study of regional parameters and structural characteristics of supplying the post-industrial services has not yet been implemented. Some issues of post-industrial services in Kazakhstan were previously considered (Beisenova 2017). Our research complements and develops the results obtained by the author.

The aim of our research was to assess the regional and product profile of post-industrial services to identify development trends in the regions of Kazakhstan.

The methods of the research were methods of the structural and dynamic economic and statistical analysis. 


\section{Main results of the research}

According to the modern methodology of research of the post-industrial economy, the sector of services, which determine the features of its development, includes:

- information and communication services;

- business and professional services (that consist of architectural, scientific and technical, legal services, management consulting and a number of other business-related services).

The regional profile of the sphere of services provided to the population of Kazakhstan for the period from 2011 to 2017 is characterized by an increase in the unevenness of their production, which essentially reflects the imbalances in the development of the country's economy as a whole.

For the period from 2011 to 2017, there was a negative trend of increasing imbalance between the regions in the production of services and, as we will show later, primarily of post-industrial services. (Figure 1)

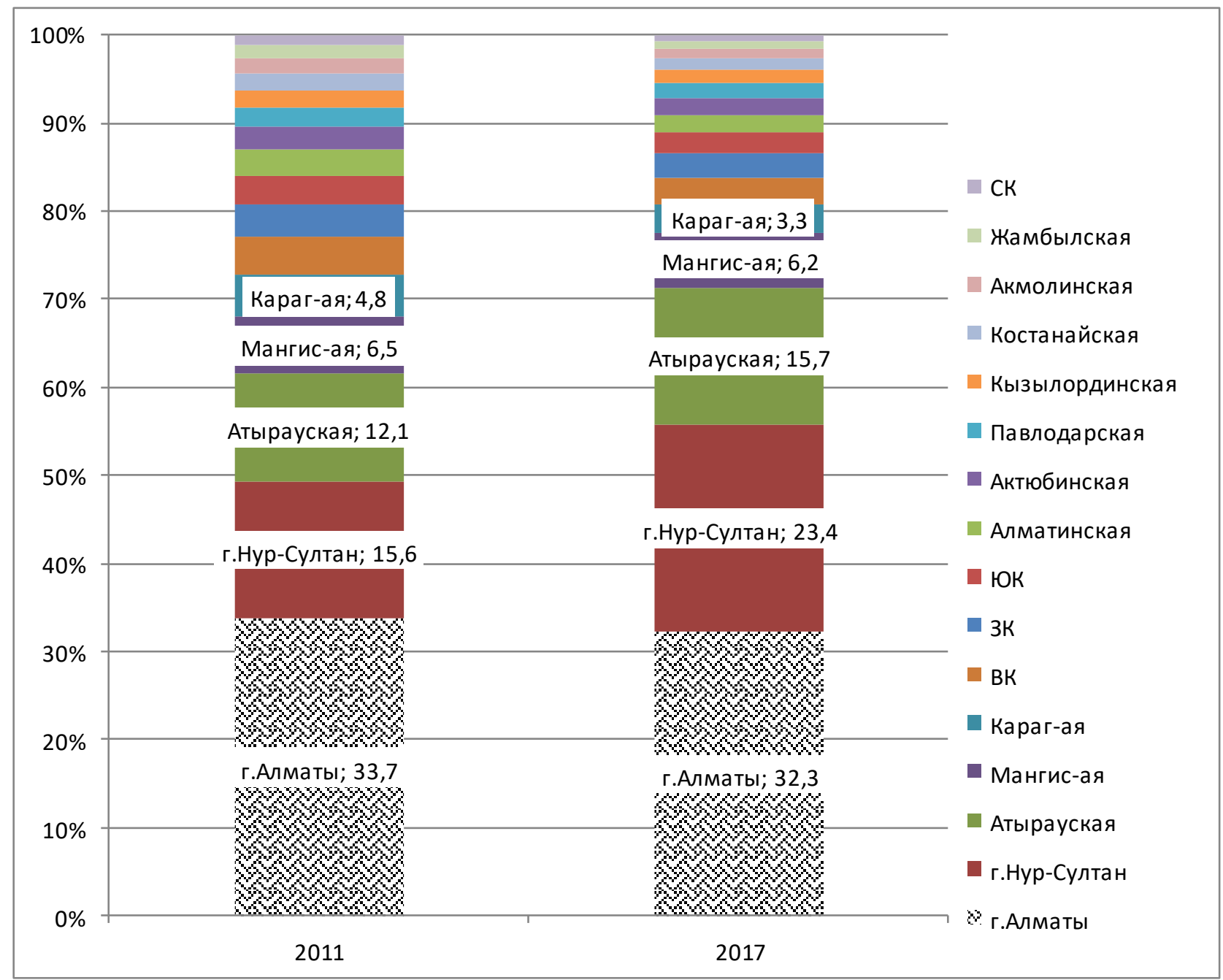

Figure 1. Regional profile of the service sector in Kazakhstan in terms of the volume of services provided by enterprises and individual entrepreneurs, 2011-2017.

Source: compiled by authors according to official website of the Committee on Statistic http://stat.gov.kz 
CK - North Kazakhstan

Жамбыльская - Zhambyl

Акмолинская - Akmola

Костанайская - Kostanay

Кызылординская - Kyzylorda

Павлодарская - Pavlodar

Актюбинская - Aktobe

Алматинская - Almaty

ЮK - South Kazakhstan

3K - West Kazakhstan

BK - East Kazakhstan

Карагандинская - Karaganda

Мангистауская - Mangistau

Атырауская - Atyrau

г.Нур-Султан - city of Nur-Sultan

г.Алматы - city of Almaty

The city of Nur-Sultan (from 15.6\% in 2011 to $23.4 \%$ in 2017) and the Atyrau region (from $12.1 \%$ in 2011 to $15.7 \%$ in 2017), which has a pronounced specialization in oil production and the production of petroleum products, increase their shares in the volume of the production of services. All other regions reduced their share in the structure of production, and in some regions there was a decrease in absolute indicators.

A rather high and growing level of concentration of these activities in several regions is also revealed. If in 2011 seven regions produced $80.7 \%$ of services, in 2017 the same regions already produce $86.6 \%$. The seven regions include two capitals of Kazakhstan, Nur-Sultan and Almaty, oil regions of Atyrau and Mangistau, traditionally industrial regions of Karaganda, East Kazakhstan, West Kazakhstan.

The centralization coefficient, equal to the sum of the squares of the specific gravities of production volumes, is 0.167 in 2011 and 0.170 in 2017, which characterizes the increasing uneven distribution of volumes between the regions of Kazakhstan (Shamoylova 2011).

Analysis of the share of different types of post-industrial services in the economies of the regions allows us to conclude that the differences between the regions are significant. Particularly significant differences are observed in technical research and architecture services, management consulting services, scientific research services, advertising and market research services (Table 1).

The general trend for all the regions is the absolute and structural growth of three types of services:

1. Computer programming and similar consulting services, which are characterized by growth in 15 regions out of 16 , while their share in the volume of services in the aggregate of regions increased from $1.5 \%$ to $3.14 \%$.

2. Information services grew in 10 regions out of 16 , while their share in the aggregate of regions increased from $1.53 \%$ to $1.67 \%$.

3. Scientific and technical services from the "other" category grew in 7 regions and their share in the aggregate of regions increased from $4.8 \%$ to $5.6 \%$.

For other services, there is neither a massive increase in the number of regions, nor positive growth trends in the aggregate share.

Thus, technical research and architecture services have positive dynamics only in the Atyrau and Kyzylorda regions, which is associated with the mineral and raw materials sector of the economy, in all other regions the share of these services has slightly decreased, and the share in the total volume has not changed. 
As for the share of post-industrial services in the total volume of services in the region (excluding education, health, trade, transport, accommodation and food), in 2017 the first places are occupied by the Atyrau region (50.1\%), the city of Almaty (42.2\%) and the city of Nur-Sultan (37.9\%), the Kyzylorda region (55.7\%). (Table 1) Table 1 - Share of the type of post-industrial services (PIS) in the total volume of services in the region, \%, 2017/2011.

Table 1. Share of the type of post-industrial services (PIS) in the total volume of services in the region, \%, $2017 / 2011$.

\begin{tabular}{|c|c|c|c|c|c|c|c|c|c|}
\hline Regions & $\begin{array}{l}\text { Computer } \\
\text { programmin } \\
\mathrm{g} \\
* *\end{array}$ & $\begin{array}{l}\text { Information } \\
\text { services } * *\end{array}$ & $\begin{array}{l}\text { Legal and } \\
\text { accounting } \\
\text { services ** }\end{array}$ & $\begin{array}{l}\text { Managemen } \\
\mathrm{t} \text { consulting } \\
* *\end{array}$ & $\begin{array}{l}\text { Technical } \\
\text { research } \\
\text { and } \\
\text { architecture } \\
* *\end{array}$ & $\begin{array}{l}\text { Scientific } \\
\text { research } * *\end{array}$ & $\begin{array}{l}\text { Advertising } \\
\text { and market } \\
\text { research } * *\end{array}$ & $\begin{array}{l}\text { Other } \\
\text { scientific- } \\
\text { technical } * *\end{array}$ & $\begin{array}{l}\text { Aggregate } \\
\text { share of PIS } \\
\text { services in } \\
\text { the region }\end{array}$ \\
\hline $\begin{array}{ll}\text { city of } \\
\text { Almaty }\end{array}$ & $4,1 / 5,14$ & $0,8 / 1,5$ & $4,4 / 3,3$ & $6 / 3,8$ & $12,2 / 10,1$ & $4,5 / 3,1$ & $14,3 / 10,6$ & $5,5 / 4,8$ & $51,8 / 42,2$ \\
\hline $\begin{array}{l}\text { city of Nur- } \\
\text { Sultan }\end{array}$ & $4,7 / 4,17$ & $5,1 / 4,2$ & $3,7 / 1,5$ & $6,8 / 14,4$ & $14,5 / 6,2$ & $6,4 / 4,1$ & $2,1 / 1,4$ & $1,2 / 5,4$ & $44,3 / 37,9$ \\
\hline Atyrau & $0,4 / 0,69$ & $0,1 / 0,1$ & $0,2 / 0,2$ & $0,5 / 0,8$ & $31,1 / 40,7$ & $1,7 / 1,2$ & $0,1 / 0,1$ & $5 / 6,3$ & $39,1 / 50,1$ \\
\hline Mangistau & $0,2 / 0,41$ & $0,1 / 0,6$ & $0,2 / 0,2$ & $0,7 / 1,1$ & $38,8 / 26,0$ & $4,4 / 4,5$ & $0,3 / 0,5$ & $0,5 / 2,1$ & $45,2 / 35,41$ \\
\hline Karaganda & $2,4 / 3,14$ & $0,7 / 0,8$ & $0,5 / 0,5$ & $0,4 / 4,7$ & $23,3 / 16,4$ & $1,9 / 2$ & $3,4 / 1,7$ & $0,7 / 2,6$ & $33,3 / 31,84$ \\
\hline $\begin{array}{l}\text { East } \\
\text { Kazakhstan }\end{array}$ & $0,9 / 1,6$ & $0,1 / 0,4$ & $0,3 / 0,4$ & $1,6 / 2,4$ & $16,4 / 17,1$ & $10,8 / 4,4$ & $2,1 / 2,2$ & $1 / 2,4$ & $33,2 / 30,9$ \\
\hline $\begin{array}{l}\text { West } \\
\text { Kazakhstan }\end{array}$ & $0,4 / 0,8$ & $0,6 / 0,2$ & $0,3 / 0,7$ & $13,4 / 1,2$ & $27,7 / 21,8$ & $0,9 / 1,6$ & $1,9 / 0,8$ & $0,4 / 1,9$ & $45,6 / 29$ \\
\hline $\begin{array}{l}\text { South } \\
\text { Kazakhstan }\end{array}$ & $0,3 / 0,76$ & $1,6 / 1,5$ & $0,7 / 0,6$ & $1,6 / 1,1$ & $30,5 / 24,3$ & $0,8 / 0,5$ & $1,9 / 1,5$ & $0,7 / 0,3$ & $36,5 / 30,6$ \\
\hline Almaty & $1,3 / 0,5$ & $0,3 / 1,2$ & $0,5 / 0,5$ & $1,7 / 5,7$ & $16,4 / 14,4$ & $1,1 / 1,4$ & $1,5 / 1,4$ & $1 / 2,1$ & $23,8 / 24,9$ \\
\hline Aktobe & $0,5 / 0,9$ & $0,7 / 1,2$ & $0,4 / 0,4$ & $0,2 / 0,4$ & $29,2 / 23,8$ & $0,2 / 0,1$ & $1,6 / 0,8$ & $0,5 / 0,6$ & $33,3 / 28,2$ \\
\hline Pavlodar & $1,4 / 2,1$ & $0,4 / 0,8$ & $0,9 / 0,6$ & $0,3 / 0,3$ & $18,1 / 16,1$ & $0,1 / 0,4$ & $3,6 / 2,3$ & $1 / 1,8$ & $25,5 / 24,4$ \\
\hline Kyzylorda & $0,5 / 0,63$ & $0,2 / 0,2$ & $0,2 / 0,3$ & $0,2 / 0,2$ & $41,3 / 50,1$ & $0,3 / 0,3$ & $0,4 / 1,1$ & $0,5 / 2,9$ & $43,6 / 55,73$ \\
\hline Kostanay & $1,2 / 3,8$ & $0,9 / 0,5$ & $0,6 / 0,7$ & $0,6 / 0,2$ & $17,8 / 17,4$ & $0,6 / 0,9$ & $1,8 / 2,6$ & $0,9 / 1,8$ & $24,4 / 27,9$ \\
\hline Akmola & $0,8 / 1,6$ & $0,4 / 0,4$ & $0,9 / 0,3$ & $0,1 / 0,2$ & $10,7 / 9,6$ & $2,9 / 1,5$ & $0,6 / 0,4$ & $0,6 / 1,4$ & $16,9 / 16,9$ \\
\hline Zhambyl & $0,5 / 0,45$ & $0,6 / 0,6$ & $0,2 / 1,1$ & $0,7 / 0,6$ & $13,8 / 9,7$ & $7,4 / 1,8$ & $1 / 1,8$ & $0,9 / 0,8$ & $25,1 / 16,8$ \\
\hline $\begin{array}{l}\text { North } \\
\text { Kazakhstan }\end{array}$ & $1,3 / 3,37$ & $0,4 / 0,7$ & $0,5 / 0,4$ & $0,2 / 0,3$ & $11,1 / 7,2$ & $0,5 / 0,4$ & $2,6 / 1,7$ & $1,5 / 1,3$ & $18,1 / 15,4$ \\
\hline $\begin{array}{l}\text { Share in the } \\
\text { total } \\
\text { volume of } \\
\text { services in } \\
\text { the RK } \\
\text { regions }\end{array}$ & $1,5 / 3,14$ & $1,53 / 1,67$ & $1,59 / 1,58$ & $6,37 / 6,28$ & $16,7 / 16,6$ & $2,8 / 2,5$ & $4,2 / 3,9$ & $4,8 / 5,6$ & \\
\hline
\end{tabular}

* The total volume does not include education and health services, transport, accommodation and food services, as otherwise, very small specific gravities will be obtained, which complicates the analysis. ** The numerator is 2011, the denominator is 2017.

Source: Compiled by authors according to official website of the Committee on Statistic http://stat.gov.kz 
To obtain an objective description of the development of the post-industrial services sector, we have conducted a rating assessment of the regions of Kazakhstan for 2011-2017 and identified areas that are leaders in each individual type of services based on the assessment of the structure of the volume of services provided for each variety (Table 2).

Table 2. Regional ratings by the structure of the volume of post-industrial services provided, average for the period of 2011-2017.

\begin{tabular}{|c|c|c|c|c|c|c|c|c|c|c|}
\hline \multirow[t]{3}{*}{ Regions } & $\begin{array}{l}\bar{\Xi} \\
\stackrel{\Xi}{\Xi} \\
\stackrel{\Xi}{0}\end{array}$ & 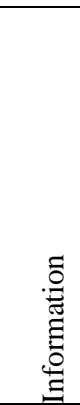 & 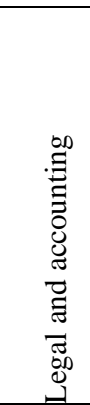 & 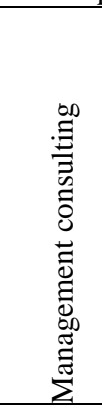 & 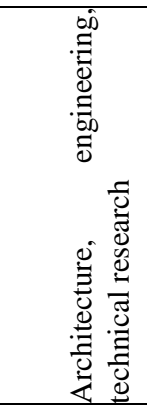 & 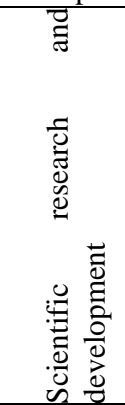 & 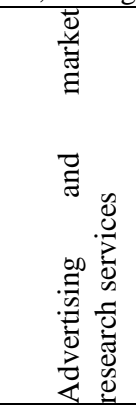 & 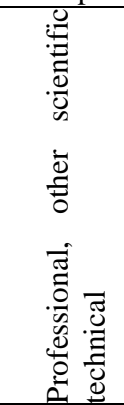 & 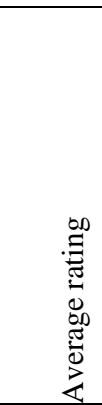 & 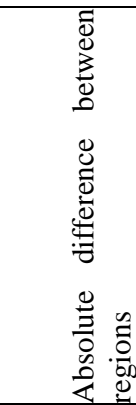 \\
\hline & 1 & 2 & 3 & 4 & 5 & 6 & 7 & 8 & 9 & 10 \\
\hline & \multicolumn{8}{|c|}{ Rating for each type of service on average for the period of 2011-2017 } & & \\
\hline city of Almaty & 1 & 2 & 1 & 1,5 & 1 & 1,5 & 1 & 1,5 & 1,3 & \\
\hline $\begin{array}{l}\text { city of Nur- } \\
\text { Sultan }\end{array}$ & 2 & 1 & 2 & 1,5 & 3 & 1,5 & 2 & 3 & 2,0 & 0,7 \\
\hline Karaganda & 3,5 & 4,5 & 4 & 6 & 6,5 & 6 & 3,5 & 7 & 5,1 & 2,9 \\
\hline Atyrau & 3,5 & 9,5 & 3,5 & 4 & 6 & 5 & 15 & 1,5 & 6,0 & 0,9 \\
\hline East Kazakhstan & 6 & 12 & 9 & 4,5 & 8,5 & 3,5 & 3,5 & 4 & 6,4 & 0,3 \\
\hline Mangistau & 10,5 & 8 & 10,5 & 7 & 3 & 3,5 & 11,5 & 6,5 & 7,6 & 1,2 \\
\hline $\begin{array}{l}\text { West } \\
\text { Kazakhstan }\end{array}$ & 10 & 8 & 8 & 4,5 & 6 & 8,5 & 9 & 9 & $\mathbf{7 , 9}$ & 0,3 \\
\hline Almaty & 9,5 & 7,5 & 8,5 & 7 & 11 & 7,5 & 7,5 & 6 & 8,1 & 0,3 \\
\hline $\begin{array}{l}\text { South } \\
\text { Kazakhstan }\end{array}$ & 13,5 & 3 & 6 & 11,5 & 6 & 12,5 & 6 & 10,5 & 8,6 & 0,5 \\
\hline Pavlodar & 7 & 9 & 7 & 14 & 12 & 12,5 & 5,5 & 9,5 & 9,6 & 1,0 \\
\hline Kostanay & 6,5 & 9 & 8,5 & 12 & 13 & 11,5 & 9 & 10,5 & 10,0 & 0,4 \\
\hline Aktobe & 11,5 & 6,5 & 13,5 & 12,5 & 9 & 16 & 11 & 13,5 & 11,7 & 1,7 \\
\hline Kyzykorda & 14,5 & 15,5 & 13,5 & 11,5 & 6 & 13,5 & 13 & 11 & 12,3 & 0,6 \\
\hline Akmola & 11,5 & 13,5 & 11 & 13 & 14,5 & 8 & 15 & 15,5 & 12,8 & 0,6 \\
\hline Zhambyl & 16 & 11,5 & 16 & 11 & 14,5 & 10 & 11 & 13,5 & 12,9 & 0,1 \\
\hline $\begin{array}{l}\text { North } \\
\text { Kazakhstan }\end{array}$ & 9,5 & 15,5 & 14 & 14,5 & 16 & 15 & 12,5 & 13,5 & 13,7 & 0,8 \\
\hline
\end{tabular}

The calculations were carried out in four stages:

1) To calculate the rating, we analyzed the volumes of services provided by enterprises and individual entrepreneurs for each year separately in the period of 2011-2017, and based on the specific gravity of the region, its rating was determined in each year. Next, the average rating for the period for each type of service was determined. Values are presented in columns 1 through 8. 


\section{INSIGHTS INTO REGIONAL DEVELOPMENT}

ISSN 2669-0195 (online) http://jssidoi.org/jesi/

2019 Volume 1 Number 4 (December)

http://doi.org/10.9770/IRD.2019.1.4(5)

2) At the next stage, the average rating for all the types of post-industrial services was calculated. The value is presented in column 9 .

3) The next step, on the basis of the method of absolute differences between rating values, has revealed groups of regions that are quite homogeneous from the point of view of the level of development of post-industrial services. The values of the absolute differences of the indicator between neighboring positions in the rating are presented in column 10. The method of absolute differences allows us to identify groups, within which the absolute deviation in the value of the indicator in question is less than between groups. Jumps in the values make it possible to distinguish groups with a sufficient degree of certainty.

According to the assessment results, the following groups were identified:

- Unconditional leaders are the cities of Almaty and Nur-Sultan, which have the first and second ratings for almost all types of services.

- Leaders of the second level are Karaganda, East Kazakhstan and Atyrau regions. They occupy stably 3,4,5 places, but in one or two types of services they have "failures". For the Atyrau region, such "failed" types of services are information (9.5 points) and market research services (15 points). For the East Kazakhstan region such services were information (12 points), legal and accounting (9 points), architectural and technical (8.5 points). In the Karaganda region, lower values are defined for engineering and other technical services (6.5 and 7 points).

- Sustainably-average regions are Mangistau, West Kazakhstan, Almaty, South Kazakhstan regions. They have one or two winning positions. The Mangistau region has 3 and 3.5 points for the development of engineering and scientific research services. The South Kazakhstan region has 3 points for the development of information services. The West Kazakhstan region has a high score for management consulting services. The Almaty region has a stable average scores for all types of services.

- Unsustainably-average regions are Pavlodar and Kostanay regions, which have almost all positions in the rating below average, but due to one or two positions with a rating above average, they will deviate from the closing group of regions. For the Pavlodar region this position is advertising and market research services (5.5 points), and for the Kostanay region this position is computer programming services. (6.5 points).

- Outsiders are Aktobe, Zhambyl, Kyzylorda, North Kazakhstan and Akmola regions, which have low ratings for all the types of post-industrial services, corresponding to low volumes of the production of these types of services. For certain types of services, they are in the field of average rating values, but the critical mass of indicators is low. Thus, the Aktobe region in the average rating zone has 6.5 points for information services, and the Kyzylorda region has 6.5 points for engineering and architecture services. The Akmola region was marked with 8 points for scientific development and research.

Analysis of the product profiles of certain types of post-industrial services allows us to see more and less dynamic intraspecific positions.

\section{Computer programming services}

The range of computer services is characterized by eight positions, but the share of these positions in the total volume of services and the growth rate of individual products vary significantly (Table 3 ).

The most demanded by the market are services on design and development of application programs, the share of which in the total volume of computer services provided has increased from $32.0 \%$ to $49 \%$. That is, by $2017,50 \%$ of the supply of services in this market segment is accounted for by services on design and development of application programs.

The growth rate of this type of services amounted to $300.5 \%$, which is $184.5 \%$ higher than the growth rate of computer services as a market segment (Table 3). 
INSIGHTS INTO REGIONAL DEVELOPMENT

ISSN 2669-0195 (online) http://jssidoi.org/jesi/

2019 Volume 1 Number 4 (December)

http://doi.org/10.9770/IRD.2019.1.4(5)

Table 3. Growth rates and structure of the computer services segment for the period of 2017/2011.

\begin{tabular}{|c|c|c|c|c|c|}
\hline \multirow[t]{2}{*}{ Types of computer services } & \multicolumn{2}{|c|}{$\begin{array}{l}\text { Volumes of services production, } \\
\text { mln. tenge }\end{array}$} & \multirow{2}{*}{$\begin{array}{l}\text { Growth rate, * } \\
\% \\
2017 / \\
2011 \\
\end{array}$} & \multicolumn{2}{|c|}{ Structure, $\%$} \\
\hline & 2011 & 2017 & & 2011 & 2017 \\
\hline Computer systems and networks management & 2943 & 687,4 & $-76,6$ & 5,4 & 0,5 \\
\hline Installation of computers and peripheral equipment & 3327,8 & 3964,70 & 19,1 & 6,2 & 2,8 \\
\hline Technical support consulting & 4199,8 & 7057,10 & 68,0 & 7,8 & 5,0 \\
\hline Other IT-services & 13623 & 23878,00 & 75,3 & 25,2 & 16,9 \\
\hline Software consulting & 5325,2 & 10052,60 & 88,8 & 9,8 & 7,1 \\
\hline Total & 54069,5 & 141501,90 & 116,3 & 100,0 & 100,0 \\
\hline $\begin{array}{l}\text { Networks and systems design and development } \\
\text { services }\end{array}$ & 2719,8 & 8088,00 & 197,4 & 5,0 & 5,7 \\
\hline IT-technologies technical support & 2653,7 & 9418,70 & 254,9 & 4,9 & 6,7 \\
\hline $\begin{array}{l}\text { Application programs design and development } \\
\text { services }\end{array}$ & 17327,4 & 69390,60 & 300,5 & 32,0 & 49,0 \\
\hline Originals of software (including computer games) & 1949,8 & 8964,8 & 359,8 & 3,6 & 6,3 \\
\hline
\end{tabular}

Another type of service that is growing more intensively than this supply of computer services in general is the originals of software (including computer games). This product in 2011 had the smallest share - 3.6\%, and in 2017 the supply was doubled to $6.3 \%$, and the growth rate compared to 2011 was $359.8 \%$.

More than the segment as a whole, the offer of technical support for IT technologies is growing - 254.9\% compared to 2011, as well as systems design and development services - 197.4\%.

All four subtypes of the computer services segment considered above increase their share in the total supply volume and represent the most promising areas of specialization for the economy of Kazakhstan. The total share of growing subtypes of computer services is $68 \%$ in 2017, while in 2011 it was $45.5 \%$.

In general, the development trend of the segment can be considered intellectual, because in the segment, it is precisely those types of services represented by "development and design" and not by "support" that grow. That is, those types of services that require a high level of vocational training and specific qualifications of human resources are growing. At the same time, the consulting subtypes of computer services are so far represented by insignificant structural shares that do not have a growth trend. That is, there is a market share, but these services have not reached the level of consulting yet.

\section{Information services}

The information services segment includes 9 positions, but as with computer services, demand for several types of services dominates. In 2011, the main demand was for data processing services $(31.7 \%)$ and infrastructure provision services for data placement (34.8\%). By 2017, demand for the first position increased and reached $40.2 \%$ of the total demand in this market segment, while the demand for infrastructure provision services decreased and amounted to $28.5 \%$ in 2017 (Table 4). 
INSIGHTS INTO REGIONAL DEVELOPMENT

ISSN 2669-0195 (online) http://jssidoi.org/jesi/

2019 Volume 1 Number 4 (December)

http://doi.org/10.9770/IRD.2019.1.4(5)

Table 4. Growth rates and structure of the information services segment for the period of 2017/2011.

\begin{tabular}{|c|c|c|c|c|c|}
\hline \multirow[t]{2}{*}{ Types of information services } & \multicolumn{2}{|c|}{$\begin{array}{l}\text { Volumes of services } \\
\text { production, mln. tenge }\end{array}$} & \multirow{2}{*}{$\begin{array}{l}\text { Growth rate, } * \\
\% \\
2017 / \\
2011 \\
\end{array}$} & \multicolumn{2}{|c|}{ Structure, \% } \\
\hline & 2011 & 2017 & & 2011 & 2017 \\
\hline Data streaming & 37,4 & 12,1 & $-67,6$ & 0,1 & 0,0 \\
\hline $\begin{array}{l}\text { Services of news agencies for newspapers, periodicals and } \\
\text { audiovisual media }\end{array}$ & 655,4 & 48,4 & $-92,6$ & 2,4 & 0,1 \\
\hline Application programs provision & 4289 & 584,5 & $-86,4$ & 15,7 & 0,8 \\
\hline Web sites processing & 795,1 & 1726,4 & 117,1 & 2,9 & 2,3 \\
\hline Infrastructure provision for data placement & 9490 & 21523,7 & 126,8 & 34,8 & 28,5 \\
\hline Total & 27259,9 & 75644,9 & 177,5 & 100,0 & 100,0 \\
\hline Data processing & 8650,7 & 30387,1 & 251,3 & 31,7 & 40,2 \\
\hline Other information services & 2541,9 & 12954,1 & 409,6 & 9,3 & 17,1 \\
\hline Web portals support & 720 & 5823,0 & 708,8 & 2,6 & 7,7 \\
\hline Providing space and time for online advertising & 80,4 & 703,1 & 774,5 & 0,3 & 0,9 \\
\hline
\end{tabular}

In 2017, the third most important center of attraction for demand was the group of diversified services, which attracted $17.1 \%$ of demand.

The analysis of growth rates in this market segment allowed us to conclude that the demand for data processing services, web portals support, and other information services is growing higher than the segment average. The highest growth rate is demonstrated by the service of providing space and time for online advertising, the growth rate of which amounted to $774.5 \%$.

At the same time, a number of positions significantly reduced their production volumes. This applies to data streaming, application programs provision, services of news agencies for newspapers, periodicals and audiovisual media.

Positive growth rates, but lower than in the segment as a whole, were recorded in the web sites processing services, as well as in the infrastructure provision for data placement.

Assessing the dominant trend in this market segment, it can be noted that the "data processing" service is not an intellectual trend in the development of information services, it is rather the exploitation of various kinds of technical means for the production of information services. At the same time, this service is more high-tech in comparison with "infrastructure provision for data placement", which went to the second position in terms of supply in this market segment.

Architecture, engineering, technical testing and analysis services

The dominant type of services in terms of their specific gravity in this segment is geology and geophysics services, which generally corresponds to the outstripping growth rates of the mining industry in the economy of Kazakhstan. This group includes mineral exploration and assessment services, land surveying services, cartography services. In 2011, this type of services occupied a share of 36.1\% of the market, but in 2017 its share fell to $31.7 \%$ and leadership shifted to another group. (Table 5). 
INSIGHTS INTO REGIONAL DEVELOPMENT

ISSN 2669-0195 (online) http://jssidoi.org/jesi/

2019 Volume 1 Number 4 (December)

http://doi.org/10.9770/IRD.2019.1.4(5)

Table 5. Growth rates and structure of the architecture, engineering, technical testing and analysis services segment for the period of $2017 / 2011$.

\begin{tabular}{|l|l|l|l|l|l|}
\hline Types of computer services & \multicolumn{1}{|l|}{$\begin{array}{l}\text { Volumes of services production, mln. } \\
\text { tenge }\end{array}$} & $\begin{array}{l}\text { Growth rate, } \\
* \%\end{array}$ & \multicolumn{2}{l|}{ Structure, \% } \\
\cline { 2 - 6 } & 2011 & 2017 & $2017 / 2011$ & 2011 & 2017 \\
\hline Planning of cities, lands, parks, etc. & 13620,9 & 4717,5 & $-65,4$ & 3,2 & 0,6 \\
\hline Architectural services of all kinds & 90662,9 & 128206,4 & 41,4 & 21,1 & 17,6 \\
\hline Total & $\mathbf{4 2 8 9 1 0}$ & $\mathbf{7 2 9 8 2 7 , 1}$ & $\mathbf{4 2 , 0}$ & $\mathbf{1 0 0 , 0}$ & $\mathbf{1 0 0 , 0}$ \\
\hline Technical testing and analysis & 62562,1 & 92689 & 48,2 & 14,6 & 12,7 \\
\hline Geology and geophysics & 154888,4 & 231401,8 & 49,4 & 36,1 & 31,7 \\
\hline Engineering services & 107176,1 & 272810,3 & 154,5 & 25,0 & 37,4 \\
\hline $\begin{array}{l}* \\
\text { Sll types of services include consulting in the corresponding field. } \\
\text { Source: Compiled by the author by source Zenka et al. 2017 }\end{array}$ & & \\
\hline
\end{tabular}

This group was engineering services, including such services as design of buildings, power plants, vehicles, waste processing plants (hazardous and non-hazardous). This also includes a segment of services for the design of industrial and technological processes, the design of communication and broadcasting lines, the design of water, drainage, and sewer systems. In 2017, the share of engineering services increased to 37.4, and this type of activity moved to the first place in demand in the services market.

Architectural services of all kinds began to occupy the third place in the services market in the segment they occupied. The share of this type of service decreased from $21.1 \%$ to $17.6 \%$.

The third place in terms of growth rates exceeding the average growth rate in the segment was taken by technical testing and analysis services (48.2\%). The latter group includes such services as purity analysis and air composition testing, physical properties testing and analysis, testing and analysis of complex electro-mechanical systems, technical control of road vehicles, etc.

Services on planning of city, lands, and parks have the smallest share and negative growth rates. The share was $3.2 \%$ in 2011 and only $0.6 \%$ in 2017 .

\section{Conclusions}

Thus, according to the results of the analysis made, the following conclusions can be drawn:

1) In the development of the services sector in Kazakhstan, a high level of concentration of these activities in several regions is observed. If in 2011 seven regions and cities of the republican significance produced $80.7 \%$ of services (excluding education, health, transportation, accommodation and food), then in 2017 the same regions already produce $86.6 \%$ of services. The centralization coefficient, equal to the sum of the squares of the specific gravities of production volumes, is 0.167 in 2011 and 0.170 in 2017, which characterizes the growing unevenness in the distribution of volumes between the regions of Kazakhstan. The ranking of the regions of Kazakhstan by the volume of services provided for the period from 2011 to 2017 showed that the ranks of the regions did not change. The leaders are the cities of Almaty and Nur-Sultan, followed by the oil Atyrau and Mangistau regions, which are ahead of the traditional industrial regions of Karaganda, East Kazakhstan, and West Kazakhstan.

2) If we turn to the analysis and assessment of post-industrial services, then for the period under review, the Karaganda and East Kazakhstan regions are included in the group of second-level leaders along with the Atyrau region. Mangistau and West Kazakhstan regions open the third group of sustainably-average regions. Sustainablyaverage regions of Mangistau, Almaty, South Kazakhstan and West Kazakhstan have one or two winning 


\section{INSIGHTS INTO REGIONAL DEVELOPMENT}

ISSN 2669-0195 (online) http://jssidoi.org/jesi/

2019 Volume 1 Number 4 (December)

http://doi.org/10.9770/IRD.2019.1.4(5)

positions. Unsustainably-average regions are the regions of Pavlodar and Kostanay, which have almost all positions in the rating below average, but due to one or two positions with a rating above average, they will deviate from the closing group of regions. Outsiders are Aktobe, Zhambyl, Kyzylorda, North Kazakhstan and Akmola regions, which have low ratings for all the types of post-industrial services. To compile the rating, the structure of the volume of services provided for each type was used, profiles of regions for 2011-2017 were determined, and regions were grouped by types of profiles on the basis of the method of absolute differences.

3) The general trend for all the regions is the absolute and relative growth of three types of services:

- Computer programming and similar consulting services, which are characterized by growth in 15 regions out of 16 , while their share in the total volume of services in the aggregate of regions has grown from $1.5 \%$ to $3.14 \%$.

- Information services grew in 10 regions out of 16, while their share in the aggregate of regions increased from $1.53 \%$ to $1.67 \%$.

- Scientific and technical services from the "Other" category grew in 7 regions and their share in the aggregate of regions increased from $4.8 \%$ to $5.6 \%$.

For other services, there is neither a massive increase in the number of regions, nor positive growth trends in the aggregate share.

4) Analysis of product profiles of certain types of post-industrial services allows us to see more and less dynamic intraspecific positions.

So, in computer services, $50 \%$ of the supply in the domestic market is occupied by application programs development services. The growth rate of this type of services amounted to $300.5 \%$, which is $184.5 \%$ higher than the growth rate of computer services as a market segment. As a result, the development trend of the segment can be considered intellectual; this type requires a high level of professional training and qualifications. Another type of services, growing more intensively than the supply of computer services in general, is the originals of software (including computer games). This product in 2011 had the smallest share - 3.6\%, and in 2017 the supply was doubled to $6.3 \%$, and the growth rate compared to 2011 was $359.8 \%$.

In 2011, the main demand was for data processing services (31.7\%) and services on infrastructure provision for data placement (34.8\%). By 2017, demand for the first position increased and reached $40.2 \%$ of the total demand in this market segment, while the demand for infrastructure provision services decreased and amounted to $28.5 \%$ in 2017.

Services on architecture, engineering, technical testing and analysis represent the most significant segment of the domestic market of post-industrial services. The dominant type of services in terms of their specific gravity in this segment in 2011 was services on geology and geophysics, which generally corresponded to the outstripping growth of the mining industry in the economy of Kazakhstan. This group includes mineral exploration and assessment services, land surveying services, cartography services. In 2017, engineering services took the first place in terms of specific gravity and growth rates, which generally corresponded to the trend of transition to the post-industrial economy with its emphasis on high-tech services for all the sectors of the economy. 
INSIGHTS INTO REGIONAL DEVELOPMENT

ISSN 2669-0195 (online) http://jssidoi.org/jesi/

2019 Volume 1 Number 4 (December)

http://doi.org/10.9770/IRD.2019.1.4(5)

\section{References:}

Bell, D. (1986). Information society social framework. Moscow: Progress, p. 330-342.

Bell, D., Inozemtsev, V. L. (2007). The age of disunity: reflections on the $21^{\text {st }}$ century world. / D. Bell, V.L. Inozemtsev. Moscow: Free thought, $303 \mathrm{p}$.

Beisenova, Zh. (2017). Dynamics and structure of post-industrial services in the economy of Kazakhstan. Bulletin of the Karaganda University, 3(87), 137-144. https://economy-vestnik.ksu.kz/ru/content/srch/2017_Economy_3_87_2017.pdf

Demidova, L.S. (2010). Services in the modern economy. M.: IMEMO RAN., 342p. https://www.imemo.ru/files/File/ru/publ/2010/10016.pdf

Information Kazakhstan - 2020. State program. Access mode: $\underline{\text { http://egov.kz/cms/ru/articles/gp_inf_kaz_2020/ }}$

Kondratyev, V.B. (2011). Services industry in the post-industrial economy. Creative economy, 7, 128-135. https://creativeconomy.ru/lib/4541.

Kravets, A.V. (2016). Innovative development and establishment of entrepreneurial clusters: problems and solutions. Russian entrepreneurship, 22, 3083-3096. https://doi.org/10.18334/rp.17.2.2206

Kraft, J., Zaitsev, A.V. (2017). The onset of the fourth industrial revolution and the formation of market structures. Innovation Economy Issues, 7(4), 281-298. https://doi.org/10.18334/vinec.7.4.38683

Lidtka, Zh., Ogilvi, T. (2015) Think like a designer. Design thinking for managers. M.: Mann, Ivanov and Ferber, 354 p.

Lundvall B.-A. (1992). National systems of innovation: Toward a theory of innovation and interactive learning. London: Pinter Publishers, 367 p. https://doi.org/10.1080/08109029308629360

Muegge S. (2013) Platforms, Communities, and Business Ecosystems: Lessons Learned about Technology Entrepreneurship in an Interconnected World. Technology Innovation Management Review, 3, 5-15. https://timreview.ca/article/655

https://timreview.ca/sites/default/files/article_PDF/Muegge_TIMReview_February2013.pdf

N. Nazarbayev (2018) The official website of the President of the Republic of Kazakhstan. Message from the President of the Republic of Kazakhstan Nursultan Nazarbayev to the people of Kazakhstan "New Development Opportunities under the Fourth Industrial Revolution" /The message of the President of the Republic of Kazakhstan. http://www.akorda.kz/

Porter, M. (2011). Competitive Strategy: Methodology for Analysis of Industries and Competitors. M.: «Alpina Publisher», 454 p.

Rostow, U. (1973). Politics and Stages of Growth. M.: Publishing House Science, 357 p.

Sarkar S., Coelho, D. M., Maroco J. (2016) Strategic Orientations, Dynamic Capabilities, and Firm Performance: an Analysis for Knowledge Intensive Business Services. Journal of the Knowledge Economy, 7(4), 1000-1020. https://doi.org/10.1007/s13132-016-0415-3

Shamoylova, R.A. (2011). Practicum on Statistical Theory: workbook. M. Finance and Statistics, 416 p.

Tachiciu L. (2016). Impact of knowledge intensive business services on economic performance of sectors and regions. Amfiteatru Economic, 41, 5-6. https://www.amfiteatrueconomic.ro/RevistaDetalii_RO.aspx?Cod=60

Toffler, E. (2010). The third wave. M.: AST, 784 p.

Tapskott, D., Williams, E. (2009) How mass cooperation changes everything. Saint-Petersburg.: Best Business Books, 290 p. http://www.labeee.ufsc.br/ luis/egcec/livros/globaliz/Wikinomics.pdf

Weill P., Woerner S. (2018). What's your digital business model? Six questions to help you build the next-generation enterprise. Harvard Business Review Press. Boston, Massachusetts, 256 p. https://store.hbr.org/product/what-s-your-digital-business-model-six-questions-tohelp-you-build-the-next-generation-enterprise/10111? 


\section{INSIGHTS INTO REGIONAL DEVELOPMENT}

ISSN 2669-0195 (online) http://jssidoi.org/jesi/ 2019 Volume 1 Number 4 (December) http://doi.org/10.9770/IRD.2019.1.4(5)

Verchenov, L. N., Efremenko, D. V., Tishchenko, V. I. (2013). Social networks and virtual network communities. M.: INION RAN, 360 p. http://inion.ru/site/assets/files/2653/social networks and online communities 2013.pdf

Varnavskiy, V.G. (2016). US Economic Growth: Trends and Factors. World Economy and International Relations, 60(2), 26-39. https://www.imemo.ru/en/jour/meimo/index.php?page_id=685\&id=7209\&jid=7204\&jij=49

Zenka J., Novotny J., Slach O., Ivan I. (2017) Spatial Distribution of Knowledge-Intensive Business Services in a Small Post-Communist Economy. Journal of the Knowledge Economy, 8(2), 385-406. https://doi.org/10.1007/s13132-015-0260-9

https://link.springer.com/article/10.1007/s13132-015-0260-9

Zhou D., Kautonen M., Wang H. C., Wang L. (2017) How to interact with knowledge-intensive business services: A multiple case study of small and medium manufacturing enterprises in China. Journal of Management \& Organization, 23(2), 297-318. https://doi.org/10.1017/jmo.2016.23

Yerkenazym ORYNBASSAROVA, PhD, Associate Professor of the Karaganda Economic University of Kazpotrebsoyuz, Karaganda, Kazakhstan. Research interests: investment, innovation, human resources.

ORCID ID: orcid.org/0000-0002-5577-6434

Tatyana PRITVOROVA, Doctor of economic sciences, Professor, Department of economics and international business, Ye.A. Buketov Karaganda State University, Kazakhstan.

ORCID ID: orcid.org/0000-0002-6306-3960

Ergaly ABZALBEK, PhD student, Ye.A. Buketov Karaganda State University, Kazakhstan.

ORCID ID: orcid.org/0000-0001-5883-6482

Yelena PETRENKO Doctor of economics, professor, Plekhanov Russian University of Economic, 117997, Moscow, Stremyanny lane 36, Russia. Research interests: strategic management, human resources management, sustainability of companies, entrepreneurship, marketing.

ORCHID ID: orcid.org/0000-0001-6892-2392

Copyright (C) 2019 by author(s) and VsI Entrepreneurship and Sustainability Center

This work is licensed under the Creative Commons Attribution International License (CC BY).

http://creativecommons.org/licenses/by/4.0/

(c) (i) Open Access 